Niessen, James P. "Hungarian Refugees of 1956: From the Border to Austria, Camp Kilmer, and Elsewhere." Hungarian Cultural Studies. e-Journal of the American Hungarian Educators Association, Volume 9 (2016): http://ahea.pitt.edu DOI: 10.5195/ahea.2016.261

\title{
Hungarian Refugees of 1956: From the Border to Austria, Camp Kilmer, and Elsewhere ${ }^{1}$
}

\author{
James P. Niessen
}

\begin{abstract}
Camp Kilmer dominates the story of flight from Hungary in 1956-1957 for many Hungarian Americans who experienced the Revolution, and with good reason: roughly four-fifths of them came through the camp, and their subsequent integration into American life was largely successful. But it is less well known that many fifty-sixers did not share this experience: as many may have returned to Hungary as came to the US, and by far most of the refugees ended up in other countries. US restrictions on entry steered many refugees to other countries, but the US provided most of the funding for the international relief effort. This article seeks to relativize the myth of Camp Kilmer by examining the refugees' motives for leaving Hungary, their experience in Austria, and why so many ended up in the US, in other countries, or back in their homeland.
\end{abstract}

Keywords: Camp Kilmer, 1956, refugees, Austria, Switzerland, Israel, Tracy Voorhees

Biography: James P. Niessen is World History Librarian at Rutgers, the State University of New Jersey in New Brunswick, New Jersey. He is President of the American Hungarian Educators Association, and External Member of the Hungarian Academy. He earned a PhD at Indiana University, and his ongoing research focuses on the exodus of Hungarians from their homeland after the 1956 Revolution. During his term as Director of Rutgers' Public Institute for Hungarian Studies he supervised the digitization of that portion of the records of the President's Committee for Hungarian Refugee Relief that is preserved at Rutgers. These records are accessible at https://rucore.libraries.rutgers.edu/portals/hungarian/.

${ }^{1}$ This paper incorporates parts of presentations at two conferences: "Hungarian Refugees of 1956: From the Austrian Border to Camp Kilmer," American Association for Eurasian and East European Studies, Philadelphia, November 20, 2015, and "Opening the Door for Refugees: The Decision to Accept 56ers in Switzerland, Israel, Canada, and the US," American Hungarian Educators Association conference, University of Maryland, April 29, 2016. I appreciate the useful comments from audience members, colleagues, and this journal's anonymous reviewers. 
Niessen, James P. "Hungarian Refugees of 1956: From the Border to Austria, Camp Kilmer, and Elsewhere." Hungarian Cultural Studies. e-Journal of the American Hungarian Educators Association, Volume 9 (2016): http://ahea.pitt.edu DOI: 10.5195/ahea.2016.261

Camp Kilmer was a fundamental experience for many Hungarian Americans: thirty-two thousand refugees of the Revolution of 1956, or eighty-five per cent of all the fifty-sixers who came to the US, passed through this military installation in Piscataway in central New Jersey. One can say that the numerical preponderance of the experience among fifty-sixers, the undeniable success of the authorities in processing this number in only five months, and the later success of the refugees in their new home attained a mythical status for Camp Kilmer. Without a doubt, the experience constitutes a special case in the history of Hungary and of US immigration. This article seeks to place the Camp Kilmer experience in the context of those years' total Hungarian emigration.

Some 200,000 Hungarians left their country between the outbreak of the Revolution on October 23, 1956 and April 1957. A report on this emigration by the Hungarian Statistical Office published for the first time in 1991 noted that the Austrian Ministry of the Interior registered 174,704 Hungarian entries up to April 6, while the Yugoslav Ministry of Interior registered 19,181 up to May 26, 1957. An estimated 5,000-10,000 entered Austria without being registered (Központi Statisztikai Hivatal 1991: 174). By the end of 1957, between 32,000 and 38,000 had come to the US, and by 1960 a few thousand more (Puskás 2000: 272-7). The rapid course of events in Hungary largely determined the short time frame, with small numbers crossing the border in the days following October 23, then an increasing flood after the second Soviet military intervention in Budapest on November 4. For several weeks the border was controlled only minimally, with Hungarian and even some Soviet forces looking the other way. 113,810 persons crossed in November, subject to progressively more rigorous control later in the month, and, finally, substantial but declining numbers crossed in successive months before the border was effectively closed off in March and crossings became very difficult and dangerous. The later trickle of Hungarians into the US by 1960 came from the camps in Austria or after stays in third countries.

A compilation on January 1, 1959 by ICEM (the Intergovernmental Committee on European Emigration) reported 200,400 Hungarians had left the country since October 1956, chiefly 179,000 to Austria, and 19,900 to Yugoslavia. Of these, 16,700 had returned to Hungary, 27,235 remained in refugee camps in Austria, Yugoslavia, and Italy, and 156,465 travelled further, 77,300 to other European countries, and 79,165 to non-European countries, chiefly in North America (Sós 2006: 124-5).

The variety of destinations and of political contexts helps explain why the collection of brief studies by Péter János Sós in Magyar exodus ['Hungarian Exodus'] may be the only booklength attempt at an overview of the worldwide emigration. Sós introduces the volume by reflecting on the inspiration for his fascination with the fate of the refugees: that he lived his life in Hungary after 1956 only because his parents stayed to care for his elderly grandparents. He adds that his generation was divided by this fateful decision to leave or to stay (Sós 2006: 9-10).

The immigrants' decision to leave their homeland seems deceptively simple from an American Cold War perspective: they were fleeing from past or future persecution and in anticipation of future reprisals. Interviews in James Michener's Bridge at Andau (1957), Martin Bursten's Escape from Fear (1958), and other surveys of the emigrants led to the conclusion that motives of fear and of opportunity - that is, the push of Communist repression and the pull of political and economic freedom - were both present in the decision of many emigrants to leave. A survey conducted with a representative sample of 1007 refugees in Vienna in December 1956 posed the question: "What were your own main reasons for leaving Hungary?" By a small 
Niessen, James P. "Hungarian Refugees of 1956: From the Border to Austria, Camp Kilmer, and Elsewhere." Hungarian Cultural Studies. e-Journal of the American Hungarian Educators Association, Volume 9 (2016): http://ahea.pitt.edu DOI: 10.5195/ahea.2016.261

margin, the majority selected fear: fear of deportation, fear of persecution, or fear of reimprisonment (International Research Associates 1957: iv-v).

The fear of reprisal appears to be vindicated as a motive by the fact that at least 22,000 people were convicted by Hungarian courts after the repression of the Revolution, and at least 229 were executed (Alföldy 1957: 39-41). There were, of course, genuine freedom fighters among the refugees, who were eagerly interviewed by the Western press. It is estimated, however, that veterans of actual street fighting accounted for no more than five per cent of the emigrants (Puskás 2000: 274). A larger number were members of Workers' Councils during the Revolution, but even including this group those who were involved with the revolution in any direct way still represented a minority.

The motive of fear of a different sort is evident in the decision of Jewish refugees to emigrate. During the Revolution there were many individual acts of violence against Jews, primarily in eastern Hungary, and anti-Semitic graffiti and slogans were reported in Budapest. The Kádár regime published a White Book that recounted anti-Semitic incidents of the "counterrevolution." The degree to which these incidents were truly widespread and characteristic of the Revolution came to be subsumed by the controversy over the regime's account of 1956 in general. The historian David Irving, who became infamous as a Holocaust denier, received official support for the research in Hungary on his 1981 book in which he asserted that the Revolution was an anti-Semitic uprising (Irving 1981, Mink 2000). The generally negative reviews of this book fail to note that Irving makes little serious effort to substantiate his controversial thesis and completely neglects it after the initial chapters.

The baseline for estimates of the Jewish population in Hungary in this period is the census for 1949, which recorded 133,862 persons of Jewish religion (Valuch 2004: 556). Estimates for the Jewish population in 1956 are based largely on subtraction for emigration in the intervening period. It appears that roughly one-third of the Jewish population of Hungary in 1956, between 15,000 and 30,000 according to various estimates, chose to leave the country after the Revolution. Fear, whether of resurgent anti-Semitism or of the Soviet crackdown, but accentuated by the recent trauma of the Holocaust, helps explain the disproportionately large Jewish emigration (Komoróczy 2012: 1032-40, Győri Szabó 2009: 254-71).

The decision to flee was facilitated in 1956 by the international position of both Yugoslavia and of Austria. Nearly one-tenth of refugees fled to Yugoslavia, chiefly from Hungary's southern counties. Although Tito's Yugoslavia had reconciled with the Soviet Union, it was sympathetic to the foreign policy of Imre Nagy and therefore refugees to Yugoslavia were interned but not repatriated to Hungary against their will, and those who desired to leave for the West were eventually able to do so.

The position of Austria was considerably more favorable to the refugees than that of Yugoslavia. The Austrian State Treaty of May 1955 provided for the departure of Soviet and other occupying troops and Austria's self-declaration (and importantly, self-definition) of permanent neutrality. Communist Hungary was so desirous of friendly relations with Austria, and evidently not hindered in this attitude by the Soviets, that it acceded to Austria's demand for the relaxation of border controls. The demolition of the Iron Curtain with Austria began in the summer of 1956 and continued even in the days before October 23, a process that was a necessary, though not sufficient, condition of the virtually free movement across the border in the weeks after November 4 (Gémes 2010: 43-51). 
Niessen, James P. "Hungarian Refugees of 1956: From the Border to Austria, Camp Kilmer, and Elsewhere." Hungarian Cultural Studies. e-Journal of the American Hungarian Educators Association, Volume 9 (2016): http://ahea.pitt.edu DOI: 10.5195/ahea.2016.261

The Austrian State Treaty left not only the act of declaring neutrality up to Austria, but also how Austria would choose to define this neutrality. Its commitment to military neutrality was solid, but also its commitment to a multiparty parliamentary system and free enterprise. Austria reacted sensitively to intimations from both the Soviet and American sides that it had violated its neutrality. On the one hand it required reporters of Radio Free Europe, alleged by the Soviets to be spies, and also anti-Communist émigré politicians, to leave Austria during the Hungarian crisis (Gémes 2006: 207-31). On the other hand, an allegation in the German American press that Austria was surrendering to Soviet pressure, and repatriating Hungarian defectors, caused Austria already in May 1956 to assure the US that it would protect the rights of those seeking asylum in the West. ${ }^{2}$

During the 1956 crisis itself, Austria issued an "order to shoot" any armed violators of Austrian territory. Troops of the fledgling Austrian army acted upon this order when a Soviet soldier crossed the border from Hungary in pursuit of a refugee. The Soviet soldier was shot on Austrian territory near the town of Rechnitz on November 23, but it is interesting that, after Austria returned the body, the Soviets made only a mild protest against the killing (Schmidl 2006: 93-115).

The warmth of the Austrian reception for the Hungarians, by farmers and urban volunteers of charitable organizations, the government at its highest level, and its agencies at all levels, invites comparison to the scenes of Germans welcoming the refugees arriving in German train stations in 2015. The Austrian government overcame its lack of preparedness for the initial flood of refugees and managed to distribute them effectively around the country among at least two hundred and fifty-seven camps. Government agencies, international organizations, and local and foreign volunteers supplied the refugees with food and medicine, and organized their further transport, so that by the end of April 1957 only 18,252 refugees remained in the country (Kern 1959). James Michener famously wrote in his Bridge at Andau: "If I am ever required to be a refugee, I hope to make it to Austria" (Michener 1957: 239). The Hungarian historian Katalin Soós agrees: "In a moral sense, Austria behaved..., with its declaration and protection of the right of asylum, like a great power" (Soós 1998: 59).

Austrian actions were doubtless inspired by both altruism and the opportunity to enhance the country's image, which had been tarnished by its participation in the Third Reich. Austria's Minister of Interior, the Socialist Oskar Helmer, played a crucial role in the very humane Austrian response. His postwar career had paired an engagement for workers' rights and compassionate treatment of German expellees from Eastern Europe with defiance of the Soviet occupiers and advocacy for the political rehabilitation of ex-Nazis in Austrian politics (Helmer 1957, Knight 2014).

${ }^{2}$ Österreichisches Staatsarchiv. Bundesministerium für auswärtige Angelegenheiten ['Austrian State Archives. Federal Ministry for Foreign Affairs']. Sektion II-pol. AdR/01. Karton 368. 1956 [folder] 6, Amerika.Foreign ministry dossier dated May 22, 1956, inspired by a January 8 article in the New Yorker Staatszeitung by Julius Epstein, "Sie waren umsonst geflüchtet: zur Lage der Flüchtlinge in Österreich" ['They emigrated in vain: On the Situation of Refugees in Austria'], concerning alleged Austrian deportation of Hungarian defectors. 
Niessen, James P. "Hungarian Refugees of 1956: From the Border to Austria, Camp Kilmer, and Elsewhere." Hungarian Cultural Studies. e-Journal of the American Hungarian Educators Association, Volume 9 (2016): http://ahea.pitt.edu DOI: 10.5195/ahea.2016.261

On October 28, the Austrian government declared that it would grant asylum to all Hungarian refugees, discounting the distinction between political and economic migrants that was important in international law. Austria met the ensuing emergency by eventually opening two hundred and fifty-seven refugee camps in all the provinces of the country. Helmer managed the process and ensured that refugees were distributed to the provinces according to a formula. For eight months, he chaired a Ministerial Committee for the Coordination of Refugee Assistance, and received daily reports. He was tireless and quite successful in lobbying for financial support from the international community, and especially the US, to pay for refugees' housing, meals, transport, and other expenses in 1956 and 1957. Helmer argued to the Austrian Cabinet on April 30, 1957 for the acceptance of additional Hungarian refugees coming by way of Yugoslavia by stating: "We have made a name for ourselves in the entire world thanks to refugee affairs. If we now take a negative position, then that good impression would be destroyed" (Haslinger 1997: 162). For public consumption, though, Helmer stated: "Das Asylrecht kommt aus dem Herzen" ['The right to asylum comes from the heart'] (Kern 1959: 5).

As the flood of refugees grew, it became clear that Austria was in no position to offer permanent asylum to all. Fortunately, many refugees had other destinations in mind. ICEM, in registering the refugees inquired about their preferred destination. Overwhelmingly, it was the US. Another survey, of 10,520 refugees between November 22 and 26 found that between 45 and 54\% of those desiring to travel beyond Austria wanted to settle in the US. (Kern 1959: 80; Glant 2007: 157-8). As we will see, the US proved unwilling to receive anywhere close to half of the final refugee count.

There was tremendous international interest in the Hungarian events, and sympathy for the refugees as fugitives from Communist repression. Potential host countries, in response to insistent appeals by Oskar Helmer and sympathy for the refugees, offered to take some of the Hungarians, even with minimal screening or preconditions. As the British journalist Claire Sterling wrote in an article published in 1958:

"Never before in the history of modern immigration," says one relief official, "have people who have just crossed the frontier heard loudspeakers saying 'Who wants Sweden, Switzerland, Belgium...' and then simply gotten into a bus marked 'Sweden,' 'Switzerland,' or 'Belgium'”' (Sterling 1958: 22).

Fortunately for the morale of the refugees and for those managing the camps, the Hungarians were in many cases moving rapidly to third countries. Bursten's generally reliable account includes a table about the chief destination countries with relation to population and national income "toward the end of the summer of 1957"3:

\footnotetext{
${ }^{3}$ Bursten 1958: 126. He does not identify his source for the data.
} 
Niessen, James P. "Hungarian Refugees of 1956: From the Border to Austria, Camp Kilmer, and Elsewhere." Hungarian Cultural Studies. e-Journal of the American Hungarian Educators Association, Volume 9 (2016): http://ahea.pitt.edu DOI: 10.5195/ahea.2016.261

\begin{tabular}{|l|c|c|c|c|c|}
\hline Country & $\begin{array}{l}\text { \$ Billion } \\
\text { national } \\
\text { income }\end{array}$ & Population & $\begin{array}{l}\text { Refugees } \\
\text { admitted }\end{array}$ & $\begin{array}{l}\text { Per } \\
100,000 \\
\text { population }\end{array}$ & $\begin{array}{l}\text { Per } \$ 100 \\
\text { million national } \\
\text { income }\end{array}$ \\
\hline Australia & 9.4 & $9,400,000$ & 8,500 & 92 & 61 \\
\hline Belgium & 7.4 & $8,868,000$ & 3,500 & 40 & 48 \\
\hline Canada & $\mathbf{2 1 . 6}$ & $\mathbf{1 5 , 8 6 1 , 0 0 0}$ & $\mathbf{3 3 , 5 0 0}$ & $\mathbf{2 1 4}$ & $\mathbf{1 5 8}$ \\
\hline France & 35.5 & $43,300,000$ & 10,000 & 23 & 28 \\
\hline W. Germany & 30 & $49,995,000$ & 12,000 & 24 & 40 \\
\hline Israel & $\mathbf{9 3 7}$ & $\mathbf{1 , 8 5 0 , 0 0 0}$ & $\mathbf{2 , 0 0 0}$ & $\mathbf{1 1 1}$ & $\mathbf{2 1 5}$ \\
\hline Netherlands & 6.3 & $10,808,576$ & 3,000 & 30 & 49 \\
\hline Sweden & 8.0 & $7,250,112$ & 6,000 & 83 & 75 \\
\hline Switzerland & $\mathbf{5 . 4}$ & $\mathbf{4 , 9 8 7 , 0 0 0}$ & $\mathbf{1 0 , 5 0 0}$ & $\mathbf{2 1 4}$ & $\mathbf{1 9 6}$ \\
\hline UK & 42.6 & $\mathbf{5 1 , 2 2 1 , 0 0 0}$ & 21,000 & 41 & 51 \\
\hline US & $\mathbf{3 4 2 . 4}$ & $\mathbf{1 6 7 , 4 4 0 , 0 0 0}$ & $\mathbf{3 4 , 0 0 0}$ & $\mathbf{2 2}$ & $\mathbf{1 0}$ \\
\hline
\end{tabular}

The table highlights some surprising disproportions that I have bolded. The largest number of refugees was accepted by the US, and all but 2000 of these passed through Camp Kilmer. But in relation to population and national wealth, the Canadian and Swiss hospitality is much more impressive, and in comparison to national wealth Israel ranks first. How can we explain this result?

Let us consider, in turn, the decision to receive refugees of the four major destination countries: Switzerland, Canada, Israel, and the US. The performance of Switzerland stands out both as one of the earliest responses and the largest relative to population. The reception of refugees proceeded in several stages. The Swiss Federal Council announced already on November 6, in response to an Austrian appeal, that it would accept 2000 refugees. It raised the number to 4000 on November 13, and committed to an additional 6000 on November 27. The first arrivals on November 11 came by a special train of the Swiss Red Cross directly from the largest Austrian camp in Traiskirchen near Vienna, who were quickly distributed to receiving communities. Subsequent contingents arrived more discretely, and were received by military personnel in camps where discipline and efficiency were valued more than manifestations of popular enthusiasm. It came to be understood that Switzerland was only an interim destination for many, and indeed of 13,803 refugees arriving in the country by the summer of 1957, 4,343 had already left (Kecskés 2016).

The generous Swiss reception helped compensate for the country's poor political image. It was revealed in the 1950s that Switzerland had not only refused to receive refugees from Nazi Germany before and during the war years, but profited from its participation in the Axis war economy. The open door policy for Hungarian refugees was a welcome release for the Swiss population from the moral burden of that history as well as a manifestation of sympathy for Austria. As another neutral country, Switzerland sought to help Austria by relieving some of its refugee burden. For these two neutral countries even more than Western countries generally, the warm reception accorded the refugees also had the character of an anti-Communist demonstration (Ludi 2014, Kecskés 2016). 
Niessen, James P. "Hungarian Refugees of 1956: From the Border to Austria, Camp Kilmer, and Elsewhere." Hungarian Cultural Studies. e-Journal of the American Hungarian Educators Association, Volume 9 (2016): http://ahea.pitt.edu DOI: 10.5195/ahea.2016.261

While Austrian and Swiss actions were inspired by a desire to burnish one's international reputation and demonstrate an opposition to Communism despite formal neutrality, the proffered hospitality was conditioned by the expectation that many of the Hungarians would travel on to third countries. The Canadian decision on November 28 to accept large numbers of refugees was a response to popular pressure on an initially reluctant federal government. The pressure was inspired by admiration for the Hungarians and by humanitarian sentiments, and a significant role was played by the Christian churches. The promised economic benefit of gaining young, motivated Hungarian workers for that large, sparsely populated country was also an argument for opening the doors. A government airlift brought the refugees over in 350 flights from December through September. Although the reception of refugees by the US largely ended in March 1957, the Canadian airlift lasted until September. By some estimates, Canada ultimately received more refugees than the US (Hidas 2006: 223-55).

It is estimated that as many as two thirds of Jewish refugees from Hungary settled in the US, the United Kingdom, and other Western countries, and only one third went to Israel despite efforts of the Israeli government to attract immigrants with generous scholarships and housing (Győri Szabó 2009: 271, Komoróczy 2012: 1037). Zionism and aliyah to Israel were powerful motives in this population, but were counterbalanced to a large degree by the attraction of the prosperous Anglophone countries. Unlike the period of the large immigration of European Jews to Israel between 1948 and 1951, these other countries now opened their doors also to Jews (Marrus 1985: 331-9). The Jewish immigrant aid societies Hias and Joint (Joint Distribution Committee) supported immigration to these countries as well as to Israel. The recent Suez Crisis, however, highlighted the dangers of choosing Israel for one's new homeland.

What was the US doing while Switzerland and other countries were leading the way in the acceptance of refugees? In light of the refugees' preference for the US, many were asking this. Unless the doors to the US were closed, many hesitated to settle for another destination. This was understandably annoying for those officials seeking to move the refugees out of Austria. In the words of Friedrich Kern's 1959 account, the desire to emigrate to the US spread among the refugees "like a contagious disease" (Kern 1959: 53). In this view of things, it was a new desire, stimulated by rumor among the refugees, or by action or inaction by the American government. An analogy might be made to the statements by German Chancellor Merkel in 2015 that seemed to many migrants like an invitation. Another analogy would be many countries' reluctance to receive Jewish refugees in the 1930s. Michael Marrus writes: "The specter haunting refugee policy during the 1930s was that encouraging Jewish refugees from Nazism might well provoke the flight of hundreds of thousands more from Eastern Europe" (Marrus 1985: 142).

The distance of the US from Hungary helps explain why Eisenhower's White House did not feel the same urgency as the Europeans. First of all, there was the President's re-election campaign to be fought and won-which it was on November 7. Then there was the Suez Crisis, which provided the chief focus of US efforts in the UN for several days. US Secretary of State John Foster Dulles spent crucial days in the hospital with a medical emergency. Finally, the divided government under the US constitution made prompt executive action more difficult than in the parliamentary regimes of European countries.

The American response to the refugee crisis was partial compensation for the neglected promise to "roll back" Communism and intervene militarily, although political rhetoric and Radio Free Europe had raised expectations that the US would do so. Key American officials 
Niessen, James P. "Hungarian Refugees of 1956: From the Border to Austria, Camp Kilmer, and Elsewhere." Hungarian Cultural Studies. e-Journal of the American Hungarian Educators Association, Volume 9 (2016): http://ahea.pitt.edu DOI: 10.5195/ahea.2016.261

finally met about the refugee crisis on November 8, and agreed in principle to accept 5,000 refugees (one third of the number registered in Austria by this time) on the basis of the Refugee Relief Act. There was a sense of alarm over the lack of refugee screening by Switzerland and other early host countries, and agreement that the US should screen the refugees both in Vienna and in a reception center in the US But then the initiative stalled for several precious days due to a disagreement among federal departments about the appropriate procedures (Bursten 1958: 557).

President Eisenhower recognized an obligation to act, but faced legal and political obstacles. Under the Immigration Act of 1924 on the basis of the national origin of the US population in 1920, the annual quota for Hungarian admissions was only 865. The McCarrenWalter Act of 1952 instituted difficult security requirements for immigrants from communist countries, who were seen as potential communist spies; the Refugee Relief Act (RRA) of 1953 provided for 200,000 admissions from these countries over three years, but retained the same strict screening requirements. As a way to get around these immigration obstacles, in November and December 1956 the American government determined to grant 5,000 visas to the Hungarians from those remaining under the RRA, then thirty thousand more in the following months, subject to the regularization of their status by subsequent legislation.

The management of public, and congressional, opinion was a crucial aspect of American refugee policy. Here, as in Western Europe, there was great enthusiasm for the victims of communism. But there was disunity among refugee supporters about the desirability of a central reception center, and also, more seriously, unease over security concerns. The city of Detroit welcomed seventy-three Hungarians in "a civic-private welfare operation." The New York Times would argue later, and this was seconded by some Hungarian organizations, that reception of the refugees should be decentralized. Kálmán Révész, the National Director of the American Hungarian Federation, telegrammed American authorities on December 27 to propose the dispersal of the refugees at "auxiliary dispersal camps in lerger [sic] American cities." 4

However, the federal government insisted upon centralized processing and entrusted its coordination to Tracy Voorhees as representative of the President with government departments and relief organizations. Voorhees hired a public relations firm to project a positive image of the refugees, emphasizing their youth, level of education, and readiness to work. The government expanded its refugee target to 21,500 at the end of November by resorting to an obscure parole provision of the immigration law of the 1952 Immigration and Naturalization Act, and eventually 32,000. The deployment of military ships and planes brought a rapid expansion in the population of Camp Kilmer, which reached its highest level in mid-January 1957.

Another distinctive characteristic of the American response was the large role assigned to religiously-based, non-governmental relief organizations. Many of them sent representatives to the camps in Austria. The American Friends Service Committee, Church World Service (for the

\footnotetext{
${ }^{4}$ Special Collections/University Archives, Rutgers University Libraries (New Brunswick, NJ). Tracy Voorhees Papers, telegram of Révész to Herbert Hoover, folder "Herbert Hoover, 1956-1957," in the records of the President's Committee for Hungarian Refugee Relief that are preserved as part of the http://dx.doi.org/doi:10.7282/T3DF6PKG.
} 
Niessen, James P. "Hungarian Refugees of 1956: From the Border to Austria, Camp Kilmer, and Elsewhere." Hungarian Cultural Studies. e-Journal of the American Hungarian Educators Association, Volume 9 (2016): http://ahea.pitt.edu DOI: 10.5195/ahea.2016.261

Protestants), Catholic Relief Services-National Catholic Welfare Conference or NCWC, and Hias and the American Joint Distribution Committee (the Jewish relief agency) collected American private contributions and distributed them in Austria. The CWS, NCWC, and Hias established contact with their coreligionists in the Austrian camps, and served as their intermediaries and advocates with the American and other destination countries' authorities, or in many cases directly advised the Consulate in the awarding of visas. James Michener wrote later about his assistance to refugees desiring admission to the US:

The United States had grudgingly announced that it would accept a certain number of refugees, but left their selection to religious groups in proportion to the religious affiliations of Hungary as stated in the recent census. This meant that the Catholics could choose the greatest number, the Protestants some, and the Jews not many. However, a disproportionate number of Jews fled, and we were faced with the problem of what to do with them... We taught Hungarian Jews how to be Baptists and Methodists, whose quotas were never filled...

(Michener 1973: 377).

Religion was not the sole criterion in the granting of American visas, though. At other times, consular officials gave greater weight to the presence of relatives already in the US or to qualifications for employment in the US. The criteria were not consistent.

There was also inconsistency in the announced number of refugees the US was willing to accept: the limit increased after seemingly final targets had been reached. The contest over refugee policy between "liberalizers" and "restrictionists" ultimately placed limits on US admissions and steered many Hungarians who had wanted to come to the US as their first choice to other countries. Congressman Francis E. Walter, a Democrat from Pennsylvania, was the key legislator in the field of immigration, and he swung dramatically from general support for the refugees to loud warnings about the penetration of communist spies (Bon Tempo 2008: 60-85).

The contest over whether to increase the quota was fought out within the White House during the months of January 1957. Voorhees lobbied hard for a renewed increase in the number of Hungarian admissions. When he was unsuccessful in this effort, he chose to "declare victory," informing the President on January 27 that he envisioned the end of his White House assignment by March 1. His formal letter of resignation followed on February 25, and the public announcement of the end of the US refugee program and closure of Camp Kilmer followed a few weeks later.

Refugees in several camps went on hunger strike in response to reports that the US would accept no more refugees. The largest of the reported hunger strikes was in Siezenheim near Salzburg, but others were reported in camps in Stockerau, Austria, and Knockalisheen, Ireland. Frustrated refugees were reportedly drinking, fighting, and leaving their camps without permission. Some refugees placed ads in the paper seeking a spouse in the local population (Sós 2006: 72-8).

Voorhees urged in his memo of January 27 that the US should "adopt a basic policy that will meet adequately and affirmatively the needs of the Hungarian refugees to the extent that 
Niessen, James P. "Hungarian Refugees of 1956: From the Border to Austria, Camp Kilmer, and Elsewhere." Hungarian Cultural Studies. e-Journal of the American Hungarian Educators Association, Volume 9 (2016): http://ahea.pitt.edu DOI: 10.5195/ahea.2016.261

these cannot be reasonably met by other countries... [and] act to assure proper care on a reasonable and equal basis in the camps in Austria, and a vigorous program for permanent resettlement." Voorhees and his chief advisor, former President Hoover, went even further. Departing from the traditional American approach that voluntary organizations shoulder much of the burden in care for the refugees, they argued that the US establish a permanent government agency for refugees and take the lead in the care and placement of the refugees remaining in Austria. But none of these proposals were realized (Porter 2009: 298-306). ${ }^{6}$ At least on the financial front, however, the US did take the lead. Of the roughly one hundred million dollars that were donated world-wide for the relief of the Hungarian refugees, more than seventy per cent came from American donors (Kecskés 2014, Loescher 2001: 87).

For refugees who would not find satisfactory placement in the West, the return home to Hungary would be an option. The Kádár government subsequently asserted that many young Hungarians left frivolously, on the spur of the moment and in search of adventure or deluded by Western propaganda. This assertion cannot be completely dismissed: $54.8 \%$ of the emigrants were between the ages of 16 and 29 (Központi Statisztikai Hivatal 1991: 186), five per cent of the emigrants returned to Hungary by April 30, 1957, and as many as one-fifth by October, 1960 (Szabó 2007: 187-8). The Western press reported ten thousand refugees had returned to Hungary by the end of 1957, but the Hungarian and Soviet press reported that the number was higher (Porter 2009: 313).

The Hungarian government offered a first repatriation amnesty in December 1956 and renewed the offer repeatedly, establishing an official Repatriation Committee (Hazahozatali Bizottság) under the Ministry of Interior. In his October 3, 1960 speech to the UN General Assembly János Kádár provided the highest figure for the number of returnees, 40,000; other estimates are in the tens of thousands depending on the cutoff point. According to an official Hungarian tabulation, half the returnees came from Austria and Yugoslavia, but most of the remainder came from Western Europe, and less than ten per cent from overseas. The following figures are extracted from this source:

\footnotetext{
${ }^{5}$ Special Collections/University Archives, Rutgers University Libraries (New Brunswick, NJ). Tracy Voorhees Papers, "Summary of Progress Report to the President on Hungarian Refugees," January 27, 1957, in the records of the President's Committee for Hungarian Refugee Relief. http://dx.doi.org/doi:10.7282/T3DF6PKG.

${ }^{6}$ The book-length revision of Porter's dissertation is scheduled for publication by the University of Pennsylvania Press in October 2016: Benevolent Empire: US Power, Humanitarianism, and the World's Dispossessed.
} 
Niessen, James P. "Hungarian Refugees of 1956: From the Border to Austria, Camp Kilmer, and Elsewhere." Hungarian Cultural Studies. e-Journal of the American Hungarian Educators Association, Volume 9 (2016): http://ahea.pitt.edu DOI: 10.5195/ahea.2016.261

\begin{tabular}{|c|c|c|}
\hline Destination & 1956ers settled & Returned to Hungary by 1960 \\
\hline Austria & 16,000 & 10,717 \\
\hline Yugoslavia & Unavailable & 3,148 \\
\hline Switzerland & 11,000 & 1,770 \\
\hline $\begin{array}{l}\text { Other West European } \\
\text { Countries }\end{array}$ & 61,500 & 7,607 \\
\hline Canada & 40,000 & 1,617 \\
\hline United States & 38,000 & 871 \\
\hline Australia & 12,000 & 48 \\
\hline Israel & 12,000 & 463 \\
\hline Other countries & 4,700 & 1,393 \\
\hline Total & 195,2000 & 27,634 \\
\hline
\end{tabular}

Source: A Magyar emigráció számszerü megoszlása országonként. A 99/SE/1960 számú elöterjesztés melléklete ['The numerical distribution of the Hungarian emigration by country. Supplement to the submission number 99/SE/1960']. Hungarian National Archives. Report of the Hungarian Foreign Ministry, May 1960. Central Committee folder 288f. 7/78. A note under the table estimates that an additional five to ten thousand returnees went unrecorded.

Historian Tara Zahra argues compellingly that East European opponents of emigration, from the later Habsburg Monarchy to the Communist era, sought to discourage would-be emigrants by warning that they would become wage slaves in the West (Zahra 2016: 21). Concerning the 1950s, she states that the Communists' "amnesty programs were never a numerical success." She quotes a Hungarian woman interviewed by the Columbia oral history project in 1957 who charged that the Hungarian program sought to "lure the rich people home and take their dollars and jewels as soon as they reached the border" (Zahra 2016: 242). This may have been the perception of many who rejected the call for repatriation. The Hungarian numbers show that repatriation efforts did have some success, but primarily among those who were stranded in neighboring Austria and Yugoslavia.

A controversial source about the repatriations is the work of the former émigré and spy Miklós Szabó. It is now known that before he returned to Hungary in October 1957 he had served as its secret agent in the West, as revealed in his memoir, Csendes háború ['Quiet War'] (Szabó 1984), published decades later and also documented by his files in the Historical Archives of the National Security that have survived; some have apparently been lost. As an agent in the West, Szabó infiltrated émigré political circles within Europe and exacerbated existing differences among the fifty-sixers. In 1956-1957 he ran an allegedly anti-communist, but in truth government-supported refugee aid office before announcing his return to Hungary in an October 3 press conference (Baráth 2013: 1500-6).

Szabó's two propaganda works, Homeless in the World and Home Again, published in 1960 in multiple languages, recount seemingly genuine cases of disillusioned emigrants who were welcomed home and described to him their misadventures while abroad. According to Szabó, American promises were "responsible for individual and mass tragedies" (Szabó 1960b: 53). Homeless presents interviews with fifty-five returnees who were for the most part able to regain their former jobs and pick up life where they left off. The author insisted that reports of intimidation and terror were "rumors and calumnies," and that the returnees were "treated humanely and returned to their families as quickly as possible" (Szabó 1960a: 137). We now 
Niessen, James P. "Hungarian Refugees of 1956: From the Border to Austria, Camp Kilmer, and Elsewhere." Hungarian Cultural Studies. e-Journal of the American Hungarian Educators Association, Volume 9 (2016): http://ahea.pitt.edu DOI: 10.5195/ahea.2016.261

know that this was not consistently the case, and that at least five refugees who returned home under amnesty were subsequently tried, convicted, and executed (Alföldy 1997: 132).

Demoralization did ensue for many of those emigrants who were not able to move on promptly to a third country by reason of advanced age, poor health, or because the hospitality of host countries lessened with the passage of time. For example, due to the lack of coordination with international organizations, the refugees in Yugoslavia were interned for several months, and many of these gave up waiting and returned home. In Austria, the refugees who remained after the bulk of compatriots had moved on to third countries included a few thousand unaccompanied minors. Interviews with representatives of the UN and Hungarian and Austrian government led to the repatriation of many of these juveniles (Engelke 2006: 91-6, 145-82). The number of returnees rose over a course of years due to relatively small numbers of unaccompanied minors, much smaller numbers of deported spies, but primarily single adults living in Austria and other West European countries.

Party leader János Kádár and his advisors were very interested in the statistics about emigration and the returnees. They were under no illusion about the preciseness of their figures, but rounding the number of repatriations upward would strengthen the case that the returnees were part of a mass movement. The game with numbers was part of the leadership's strategy to spread division among the émigrés and lure many of them home. ${ }^{7}$ Kádár declared in his speech to the United Nations General Assembly on October 3, 1960:

From among the people who under the influence of mendacious propaganda had left their country, more than 40,000 have already returned home...Every Hungarian living far from his country, unless he has definitely lost his human character, is waiting for the day when he will be able to go home...The affairs of my country are in order. It offers every honest working man rights, human dignity, good living and a home not [to] be found outside the country, and waits for the return of its sons who went astray. ${ }^{8}$

This propagandistic sally before the UN may not have convinced many of Kádár's listeners, especially those who doubted his numbers. Repatriation was a contested reality, and the government would itself come to terms, not later than the amnesty of 1963, with the reality that most fifty-sixers would remain abroad (Szabó 2007: 208-13).

The comparison of the 1956 refugee crisis to the crisis of 2015 yields both similarities and contrasts. In 2015 Germany extended a welcome to the Middle Eastern refugees arising from the compassion of many volunteers and the determination of the government that hospitality was not only humane but would also help satisfy the labor needs of a growing economy. Similar sentiments motivated the much more widespread hospitality extended to the Hungarians in 1956-1957. While only 5\% of them were genuine freedom fighters, their flight

\footnotetext{
${ }^{7}$ Hungarian National Archives. Central Committee folder 288f. 7/78. Secretariat session of May 17, 1960.

${ }^{8}$ United Nations. General Assembly. Fifteenth Session, $883^{\text {rd }}$ plenary meeting, 338.

http://www.un.org/ga/search/view_doc.asp?symbol=A/PV.883.
} 
Niessen, James P. "Hungarian Refugees of 1956: From the Border to Austria, Camp Kilmer, and Elsewhere." Hungarian Cultural Studies. e-Journal of the American Hungarian Educators Association, Volume 9 (2016): http://ahea.pitt.edu DOI: 10.5195/ahea.2016.261

from communist repression was a Cold War propaganda win for the host countries. In 2015, the generosity of individual aid workers outside Germany and Austria faded from sight due to the prevailing concern over jobs and Islamic extremism. The security concerns of the United States served to place limits on hospitality to the Hungarians in 1956-1957, serving to channel immigrants into the other countries.

Upwards of 160,000 refugees of the Hungarian Revolution found new homes in other countries. The American total of roughly 38,000 was, in relation to the host country's population, far more modest than the admissions by Canada, Switzerland, and Israel. But the US provided the most financial support for the huge burden Austria shouldered as the refugees' interim destination. The National Academy of Sciences of the US calculated that the education of professionals and scholars who settled in the US represented an investment of thirty million dollars (Mitchell 1957). The long term benefit to the host country was higher in an economic sense, not to mention the political benefits. The youthful, often highly educated refugees were largely successful in their transition to American life and that of their other host countries.

In 1958-1959 the Hungarian ruling party's newspaper, Népszabadság ['People's Liberty'], and the London-based émigré paper Irodalmi újság ['Literary News'] presented rival surveys of how the fifty-sixers had fared in their new host countries. The party organ reported widespread unemployment, while the émigré paper asserted that unemployment was low and mostly temporary, conditioned by the refugees' initial difficulties in learning the language of the host country (Sós 2006: 128-50). While a comprehensive assessment has yet to be made, it is certain that most of the fifty-sixers were able to make a successful transition.

\section{Works Cited}

Alföldy, Géza et al. 1997. Ungarn 1956 : Aufstand, Revolution, Freiheitskampf: Vorgetragen am 29. Oktober 1996 ['Hungary 1956: Uprising, Revolution, Freedom Fight: Presented on October 29, 1996']. Heidelberg: C. Winter.

Baráth, Magdolna. 2013. "Célkeresztben az 56-os magyar emigráció" ['The '56 Emigration as Target']. Századok ['Centuries'] 6: 1497-1511.

Bon Tempo, Carl J. 2008. Americans at the Gate: The United States and Refugees during the Cold War. Princeton: Princeton UP.

Bursten, Martin A. 1958. Escape from Fear. [Syracuse:] Syracuse UP.

Engelke, Edda. 2006. “Einem besseren Leben entgegen?” Ungarische Flüchtlinge 1956 in der

Steiermark [“'Toward a Better Life?' Hungarian Refugees 1956 in Styria']. Innsbruck:

StudienVerlag.

Gémes, Andreas. 2006. "“Schade, schade, immer Spionage!” ['Shame, Shame, Always Espionage!']. In Die Ungarische Revolution und Österreich 1956 ['The Hungarian Revolution and Austria 1956’]. Eds. Ibolya Murber and Zoltán Fónagy. Wien: Czernin Verlag: 207-31 . 2010. "Wie zwei geschiedene Eheleute”: Österreichisch-ungarische Beziehungen in 1950er Jahren ['Like Two Divorced Spouses: Austro-Hungarian Relations in the 1950s']. Graz: Uni-Press Graz.

Glant, Tibor. 2007. Remember Hungary: Essays on the Hungarian Revolution and War of Independence in American Memory. Wayne, NJ: Center for Hungarian Studies and Publications. 
Niessen, James P. "Hungarian Refugees of 1956: From the Border to Austria, Camp Kilmer, and Elsewhere." Hungarian Cultural Studies. e-Journal of the American Hungarian Educators Association, Volume 9 (2016): http://ahea.pitt.edu DOI: 10.5195/ahea.2016.261

Győri Szabó, Róbert. 2009. A kommunizmus és a zsidóság Magyarországon 1945 után ['Communism and the Jews in Hungary after 1945']. Budapest: Gondolat.

Haslinger, Peter. 1997. "Zur Frage der ungarischen Flüchtlinge in Österreich 1956/57" ['On the Question of the Hungarian Refugees in Austria 1956/57']. In Migrationen und ihre Auswirkungen: Das Beispiel Ungarn 1918-1995 ['Migrations and Their Consequences: The Example of Hungary 1918-1995']. Ed. Gerhard Seewann. München: R. Oldenbourg Verlag.

Helmer, Oskar. 1957. 50 Jahre erlebte Geschichte ['Fifty Years of Remembered History']. Wien: Verlag der Wiener Volksbuchhandlung.

Hidas, Peter. 2010. “Arrival and Reception: Hungarian Refugees, 1956-1967.” In The 1956 Hungarian Revolution: Canadian and Hungarian Perspectives. Eds. Christopher Adam, Tibor Egervari, Leslie Lacko, and Judy Young. Ottawa: The University of Ottawa Press: 223-55.

International Research Associates. 1957. Hungary and the 1956 Uprising: Personal Interviews with 1,000 Hungarian Refugees in Austria. New York.

Irving, David John Cawdell. 1981. Uprising! London: Hodder and Stoughton.

Kecskés, Gusztáv. 2014. "Collecting Money at a Global Level: The UN Fundraising Campaign for the 1956 Hungarian Refugees." Eastern Journal of European Studies. 5/2 (December): 33-60. . 2016. "Az 1956-os magyar menekültek svájci befogadása" ['The Swiss Reception of the 1956 Hungarian Refugees']. Történelmi szemle ['Historical Review'] 1: 85-114.

Kern, Friedrich. 1959. Österreich: Offene Grenze der Menschlichkeit: Die Bewältigung des ungarischen Flüchtlingsproblems im Geiste internationaler Solidarität ['Austria: Open Border of Humanity: The Mastering of the Hungarian Refugee Problem in the Spirit of International Solidarity']. Wien: Bundesministerium für Inneres.

Knight, Robert. 2014. "National Construction Work and Hierarchies of Empathy in Postwar Austria." Journal of Contemporary History. 49/3: 491-513.

Komoróczy, Géza. 2012. A zsidók története Magyarországon ['The History of the Jews in Hungary']. Pozsony: Kalligram.

Központi Statisztikai Hivatal [Central Statistical Office]. 1991. "KSH-jelentés az 1956-os disszidálásról" ['KSH Report on 1956 Emigration']. Regio: Kisebbségtudományi Szemle ['Regio: Minority Studies Review']. 91/4: 174-211.

Loescher, Gil. 2001. The UNHCR and World Politics: A Perilous Path. New York: Oxford UP. Ludi, Regula. 2014. "More and Less Deserving Refugees: Shifting Priorities in Swiss Asylum Policy from the Interwar Era to the Hungarian Refugee Crisis of 1956." Journal of Contemporary History. 49/3: 577-98.

Marrus, Michael R. 1985. The Unwanted: European Refugees in the Twentieth Century. New York: Oxford UP.

Michener, James A. 1957. The Bridge at Andau. New York: Random House.

—. 1973. "On Assignment." In A Michener Miscellany: 1950-1970. New York: Random House.

Mink, András. 2000. "David Irving and the 1956 Hungarian Revolution.” The Hungarian Quarterly. Winter 2000: 117-128.

Mitchell, James P. 1957. “Freedom’s \$30 Bonus.” New York Herald Tribune. May 10. http://dx.doi.org/doi:10.7282/T31R6P67 
Niessen, James P. "Hungarian Refugees of 1956: From the Border to Austria, Camp Kilmer, and Elsewhere."

Hungarian Cultural Studies. e-Journal of the American Hungarian Educators Association, Volume 9 (2016):

http://ahea.pitt.edu DOI: 10.5195/ahea.2016.261

Porter, Stephen Ross. 2009. Defining Public Responsibility in a Global Age: Refugees, NGOs, and the American State. Diss. University of Chicago.

Puskás, Julianna. 2000. Ties that Bind, Ties that Divide: 100 Years of Hungarian Experience in the United States. New York: Holmes \& Meier.

Schmidl, Erwin A. 2006. "Die österreichische Reaktion auf die Ereignisse in Ungarn 1956 und der Einsatz des Bundesheeres an der ungarischen Grenze" ['The Austrian Reaction to the Events in Hungary 1956 and the Deployment of the Federal Army on the Hungarian Border']. In Die Ungarische Revolution und Österreich 1956 ['The Hungarian Revolution and Austria 1956’]. Eds. Ibolya Murber and Zoltán Fónagy. Wien: Czernin Verlag: 93-116.

Soós, Katalin. 1998. "Ausztria és a Magyar menekültügy 1956-57" [“Austria and Hungarian Refugee Affairs 1956-57']. Századok ['Centuries']. 132/5: 1019-51.

Sós, Péter János. 2006. Magyar exodus: Magyar menekültek nyugaton, 1956-1959 ['Hungarian Exodus: Hungarian Refugees in the West, 1956-1959']. $2^{\text {nd }}$ edition. Budapest: Gondolat.

Sterling, Claire. 1958. "What Happened to the Hungarian Refugees." The Reporter. October 8: 22-24.

Szabó, Juliet. 2007. ““...s várja eltévedt fiait is.’ Az MSZMP repatriálási és hazalátogatási politikája 1956 és 1963 között" ['... and Awaits its Wayward Sons: The Repatriation and Home Visit Policy of the MSZMP between 1956 and 1963']. Múltunk. 1: 187-213.

Szabó, Miklós. 1960a. Home again. Budapest: Pannonia Press. 1960b. Homeless in the World. Budapest: Pannonia Press. - 1984. Csendes háború ['Silent War']. Budapest: Zrínyi Katonai Kiadó.

Valuch, Tibor. 2004. "Changes in the Structure and Lifestyle of the Hungarian Society in the Second Half of the XXth Century." In Social History of Hungary from the Reform Era to the End of the Twentieth Century. Eds. Gábor Gyány, György Kövér, and Tibor Valuch. Bounder, Colorado: Social Science Monographs; Highland Lakes, New Jersey: Atlantic Research and Publications.

Zahra, Tara. 2016. The Great Departure: Mass Migration from Eastern Europe and the Making of the Free World. New York, NY: W.W. Norton \& Company. 